\title{
Reduction in Carbon Dioxide Emission and Energy Savings Obtained by Using a Green Roof
}

\author{
Lu Cai, Xiao-Ping Feng*, Jing-Yan Yu, Qian-Chao Xiang, Rui Chen \\ School of Environmental and Civil Engineering, Jiangnan University, Wuxi, Jiangsu 214122, China
}

\begin{abstract}
Green roofs have good heat preservation and insulation performance, which plays an important role in reducing airconditioning load and reducing carbon dioxide emissions. Experimental research and numerical simulation analysis on the energy-savings and ecological benefits of green roofs in hot summer and cold winter areas in Wuxi, $\mathrm{China}\left(31^{\circ} \mathrm{N}, 120^{\circ} \mathrm{E}\right)$ are carried out. The experimental results show that a new type of Buddha grass can absorb $1.79 \mathrm{~kg}$ of $\mathrm{CO}_{2}$ and release $1.3 \mathrm{~kg}$ of $\mathrm{O}_{2}$ per square meter per year. In addition, the annual carbon emission reduction of the green roof in Wuxi was $9.35 \mathrm{~kg} \mathrm{~m}^{-2}$, and the emission reduction benefit of the green roof was calculated to be USD $\$ 1.02 \mathrm{~m}^{-2} \mathrm{a}^{-1}$. The energy consumption simulation shows that the green roof per unit area can save $11.53 \mathrm{kWh}$ per year, and the annual quantitative ecological benefit of a green roof is USD $\$ 3.37 \mathrm{~m}^{-2}$. The calculated dynamic investment return is 10 years. A green roof has the benefits of heat preservation and insulation; meanwhile, it can reduce energy consumption. It is also worth mentioning that its energysaving potential and ecological benefits are substantial, and the investment payback time is short, which makes it worth promoting in a large area.
\end{abstract}

Keywords: Carbon dioxide emission; Green roof; Equivalent thermal resistance; Energy-savings; Ecological benefits.

\section{INTRODUCTION}

There have been increasing concerns about air pollutants and greenhouse gases at local, regional, and even global scales (Meng et al., 2014). Green roofs have been proposed as the sustainable practice to mitigate the adverse effects of urbanization and play an important role in reducing carbon dioxide emissions (Shafique et al., 2018). In current global energy shortage environment, green roofs provide an implementable solution for cities. The prospects for green roofs are generally bright, and the dissemination potential is substantial in European cities with temperate climates (Brudermann and Sangkakool, 2017). Mohamed et al. (2017) used a multiplier analysis to make recommendations for reducing energy and carbon dioxide. In this paper, we use the green roof method based on Buddha grass to explore methods for reducing energy consumption and carbon dioxide.

In China, a green roof is defined as three types: lawn type, garden type, and combination type, according to different planting matrices, construction costs, and plant species. Compared with the other two green forms, turf-type roof greening has advantages including low cost, fast construction, high levels of safety, easy maintenance, and easy promotion.

\footnotetext{
${ }^{*}$ Corresponding author.

E-mail address: fxp@jiangnan.edu.cn
}

Not all plants are suitable for roofing because the roof greening plant growth environment is quite different from that for plants grown on the ground. The plants used in turf-type greening have the following characteristics: low plant height, strong resistance to pests and diseases, strong adaptability to thinness, the ability to withstand high temperatures in summer and cold temperatures in winter, resistant to pruning and transplantation, a slow growth habit, and can be applied extensively. Because it is best to have an evergreen roof in all seasons, corresponding to the characteristics of hot summer and cold winter regions, Buddha grass as the roof greening plant for the purposes of this paper.

In cities found in China's four representative climate zones: Harbin, Beijing, Chongqing, and Guangzhou, the effect of green roof on energy-savings and indoor thermal comfort performance is remarkable (Zeng et al., 2017). Liu et al. (2017) found that the environmental pollution problem in Beijing is very serious and even threatens the health of the population. The use of vegetation and other methods can alleviate this phenomenon, and because of this, green roofs are being promoted internationally.

A green roof is an effective building energy-saving technology and plays a significant role in regulating temperature and heat flux (Chen et al., 2015). Research has confirmed that after a transformation to a green roof, the demand for building energy is reduced; the annual electricity consumption of the building is reduced; energy consumption is reduced, and indoor comfort is greatly improved. It can be 
seen that the energy-saving effect of a green roof is very significant (Roche et al., 2014; Pérez et al., 2015; Refahi et al., 2015; Virk et al., 2015; Berardi, 2016; Silva et al., 2016).

In addition to energy-saving benefits of green roofs, they also have a positive impact on the overall ecology of the urban environment. Yang et al. (2018) suggests that current cities need vegetation. It directly and indirectly affects the surrounding air quality, and at the same time, it reduces the generation of atmospheric pollutants. Green roofs can reduce atmospheric $\mathrm{CO}_{2}$, urban air pollution, runoff, building energy consumption, and can mitigate global warming as well as urban heat island effects.

The United States was one of the first countries to use green roofs in modern architecture. At the beginning of the $21^{\text {st }}$ century, many scholars began to analyse the energysaving and ecological potential of buildings with green roofs. Akbari (2003) conducted a comparative experiment in Sacramento, California in the summer of 2003. The data on green roofs were obtained by measuring data such as indoor and outdoor temperature, humidity, and room air conditioning energy consumption. In the energy simulation software, the building energy consumption of the room before and after greening was simulated. Akbari's results showed that a $30 \%$ energy savings for the experimental green roof, and the $\mathrm{CO}_{2}$ emissions were greatly reduced, thus achieving both energy conservation and environmental protection.

Zhang et al. (2009) used the unit cost of a green roof project to measure the economic value of the energy savings and ecological benefits of a green roof area in Beijing. In the early stage, the investment costs for different types of green roofs in Beijing were investigated separately, and the monetization of ecological benefits was equivalent to the financial income derived as a result of the green roof in the coming years. The comprehensive benefit value generated after the implementation of greening in Beijing was calculated to be USD $\$ 21.21 \mathrm{~m}^{-2}$. The energy savings and consumption reduction accounted for more than $44 \%$ of the benefits, and the ratio of the benefit of carbon sequestration and oxygen release exceeded 55\%. In comparison, the ecological benefits of water conservation accounted for only a small proportion, less than one percent of the total benefit value.

Li (2011) conducted a comparative analysis of different types of green roofs in response to the geographical location, climatic characteristics, and environmental conditions of Guangzhou, and measured the ecological value of a lightloaded building green roof in terms of purifying the air and maintaining a carbon-oxygen balance. On this basis, the most suitable plants and matrix materials in the region were screened, and a reasonable ecological greening model was proposed to deal with environmental problems in Guangzhou.
The ecological benefits of green roofs are remarkable and contribute to the sustainable development of both buildings and cities (Wang et al., 2013; Berardi et al., 2014; Peng and Jim, 2015; Richardson et al., 2016; Francis and Jensen, 2017; Kuronuma et al., 2018; Teotónio et al., 2018).

In the face of global carbon dioxide problems, Yang et al. (2019) mainly studies carbon dioxide generated by seismic fault activity. This paper implements a green roof study to prove that it can slow down this source of carbon dioxide. In view of the climate characteristics comprising a hot summer and cold winter, Wuxi is chosen as the representative city to study the energy-saving and ecological benefits of green roofs in this area. The effects on heat preservation and insulation are also investigated. The results provide a certain basis for green roof' popularization and application in hot summer and cold winter areas.

\section{METHODS}

\section{Experimental Design}

This experiment was carried out in Wuxi, China, where the representative climate is hot in the summer and cold in the winter. A comparative experiment was designed to study the thermal performance of green roofs. Assuming whether the roof of the room is green or not as a variable, comparing the changes in the internal and external surface temperature, the heat flow through the roof, and the electricity consumption of air-conditioning under the same conditions, the heat preservation and insulation effects and energy-saving benefits of a green roof are analysed. The length, width, and height of the experimental room under construction were $9000 \mathrm{~mm} \times 2000 \mathrm{~mm} \times 2500 \mathrm{~mm}$, respectively. The roof structure and thermal parameters of the experimental room are shown in Table 1. For the purposes of the experiment, two of the adjacent three equal-area rooms were selected for comparison. The layout of the experimental rooms were identical except for the roof, and the room area was $6 \mathrm{~m}^{2}$.

Studies have shown that Sedum species, which are succulent perennials, are commonly used in green roofing. A Sedum green roof has the advantage of a simple design and the fact that less heat is passed down to the indoor environment (Jim, 2015; Kadas, 2017; Vasl et al., 2017). The greening plant used in the experiment was stonecrop, a domesticated, improved plant in the Sedum family. The experiment also involved the use of self-cultivation of a roof with Buddha grass, which was cultivated from wild Buddha grass through domestication. At the same time phase change energy storage and soilless culture techniques were adopted to form the green layer structure suitable for any flat roof. After being domesticated, Buddha grass can fix carbon dioxide in

Table 1. Roof structure and thermal parameters of the experimental room.

\begin{tabular}{llllll}
\hline Structural layer & Material & $\begin{array}{l}\text { Thickness } \\
(\mathrm{mm})\end{array}$ & $\begin{array}{l}\text { Thermal } \\
\text { conductivity } \\
\left(\mathrm{W} \mathrm{m}^{-1} \mathrm{~K}^{-1}\right)\end{array}$ & $\begin{array}{l}\text { Thermal } \\
\text { resistance } \\
\left(\mathrm{m}^{2} \mathrm{~K} \mathrm{~W}^{-1}\right)\end{array}$ & $\begin{array}{l}\text { Total thermal } \\
\text { resistance } \\
\left(\mathrm{m}^{2} \mathrm{~K} \mathrm{~W}^{-1}\right)\end{array}$ \\
\hline $\begin{array}{l}\text { Outer layer } \\
\text { Middle layer }\end{array}$ & Cement pressure board & 10 & 1.5 & 0.065 & 0.763 \\
Inner layer & Extruded polystyrene board & 30 & 0.04 & 0.75 & \\
\hline
\end{tabular}


the dark to form organic acids and has the ability to survive in extremely dry, high temperature, poor substrate habitats. It is easy to conserve, has good water retention, and the water content is high. It is not necessary to artificially water, fertilize, weed, trim, replant, and control for insects, as shown in Fig. 1. The green layer consists of a grass layer and a planting tray. The planting tray is a $500 \mathrm{~mm} \times 500 \mathrm{~mm}$ plastic basket used for plants. It is made of polypropylene (PP) plastic and has drainage. Plate planting is beneficial to increase permeability and space stability, and it does not require the use of soil. The substrate used is much lower than the maximum bearing pressure of the roof surface, and the adaptability is strong. In the experiment, the green roof system utilizing self-curing stonecrop was used to form a green layer structure suitable for any flat roof. The green layer consisted of grass layers and planting trays (see Fig. 2). Under conditions where the entire planting tray was saturated with water, the weight of the green roof per unit area was only $28-30 \mathrm{~kg} \mathrm{~m}^{-2}$, which meets the current load requirements for various building roofs. The instruments used in the experiment included a temperature sensor, a heat flow meter, a hot ball anemometer, a hygrometer and a multichannel data acquisition instrument. A separate electricity meter was used to measure the power consumption of the air-conditioning unit. The layout of the test points on the experimental roof is shown in Fig. 3. The measurement points were evenly arranged in each room, and the vertical arrangement of the measurement points on the inner and outer surfaces of the roof corresponded to each other.

The experiment was conducted from June 2017 to March 2018. The data from January to February with the lowest temperature in winter were selected to calculate the thermal insulation resistance in winter, and the experimental data from July to August with the highest temperature in summer were used to analyze the heat insulation performance in summer. In the experimental stage, the climate characteristics are obvious; the moisture content of the greening matrix layer is stable; the plants grow normally, and there is no withering. The data obtained from the test were thus representative.

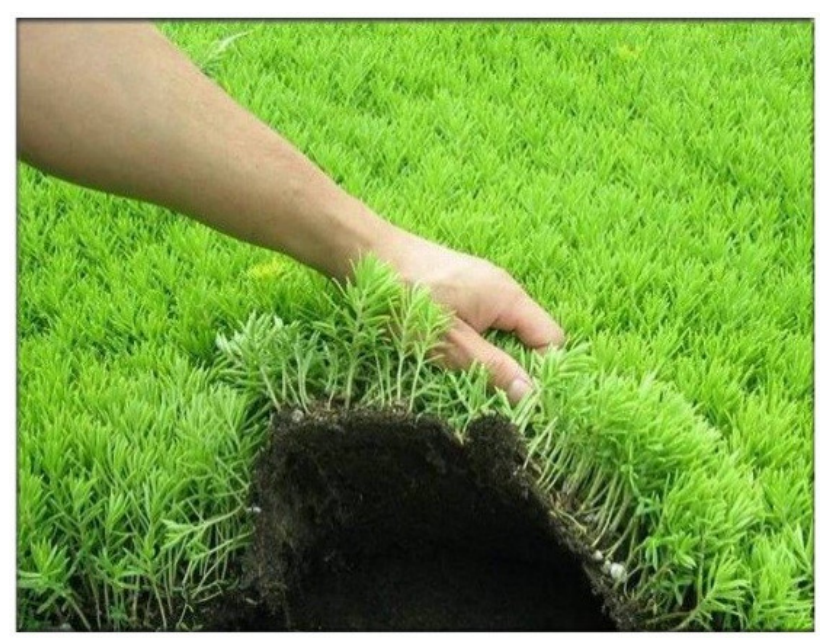

Fig. 1. Domesticated and cultivated wild Buddha.

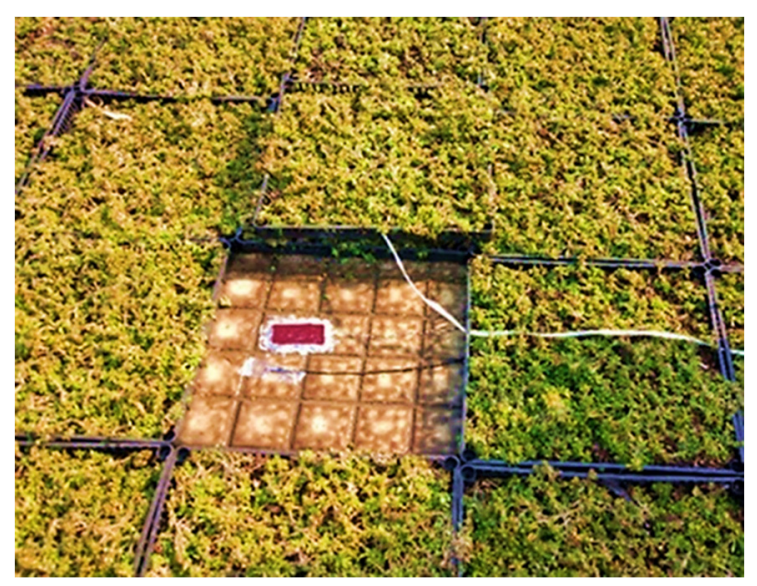

Fig. 2. Planting tray and the arrangement for roof temperature and the heat flow sensor.

Green roofs can significantly reduce the temperature fluctuation of roofs in cold climates and provide passive warming to indoor spaces (Jim, 2014; Tang and Qu, 2016). During times of snow cover, snow acts as an insulator and reduces the relative energy-saving benefits achieved by a green roof (Zhao, 2015; Squier et al., 2016; Collins et al., 2017). Green roofs can reduce the amplitude of outer surface temperature fluctuations in summer, and the cooling effect of a green roof in summer is significant on sunny days (He et al., 2016; Herrera-Gomez et al., 2017; Bevilacqua et al., 2018). Therefore, the experimental data were selected for processing in the three periods: cooling and snowfall in winter and sunny in winter and summer.

The experimental steps were as follows:

The first step: The experimental room was built with a simple frame, as shown in Fig. 4. A $200 \mathrm{~mm}$ thick XOS board (1) was attached as a wall. The plate should be used as the joint seam and the pressure sensitive tape is used to strengthen and close the wall. The roof panel could be replaced by $10 \mathrm{~mm}$ thick CCA board $+30 \mathrm{~mm}$ thick XPS board $+10 \mathrm{~mm}$ thick CCA board. (2) A normal growing planting tray was selected. (3) The module patchwork was replenished with grass, and the density was the same as the plant density in the planting tray.

The second step: The experimental room was divided into three rooms. The first room was equipped with a planting tray; the second room was used as an operating room, and the experimental equipment was located in this room for the experimenter. The third room was left as a reference room.

The third step: The test time was continuous without interruption in order to record the experimental data. The test was considered valid when the last calculated value of the equivalent thermal resistance differed from the calculated value before $24 \mathrm{~h}$ by no more than $10 \%$.

The fourth step: The equivalent thermal resistance was analyzed using an arithmetic mean method.

\section{Heat Preservation Effect}

In order to obtain the heat preservation effects gained by the use of a green roof, the experiment was carried out at low temperature in winter. During the experiment, the indoor 
(a)

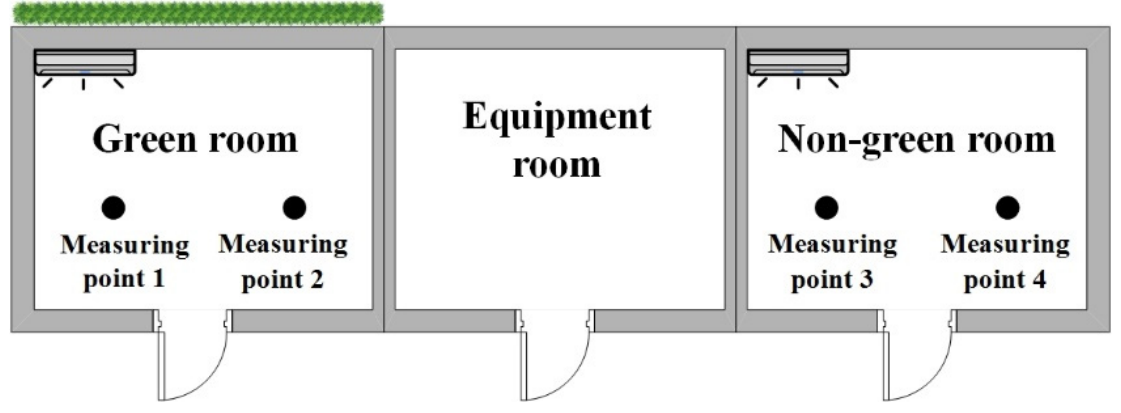

(b)

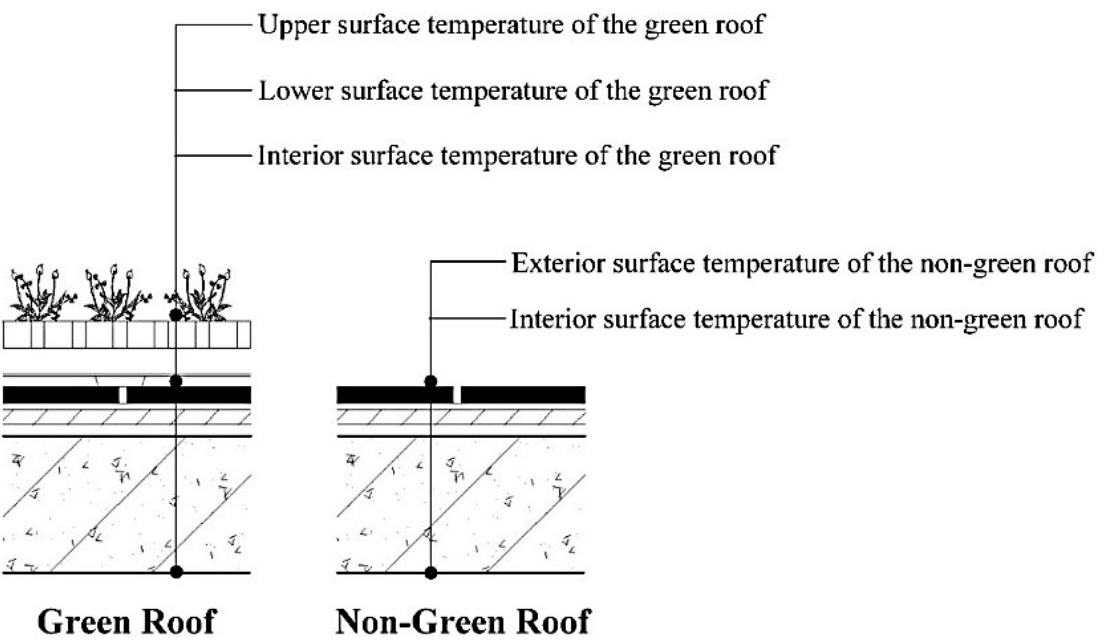

Fig. 3. (a) Horizontal and (b) vertical measurement points on the experimental roof.

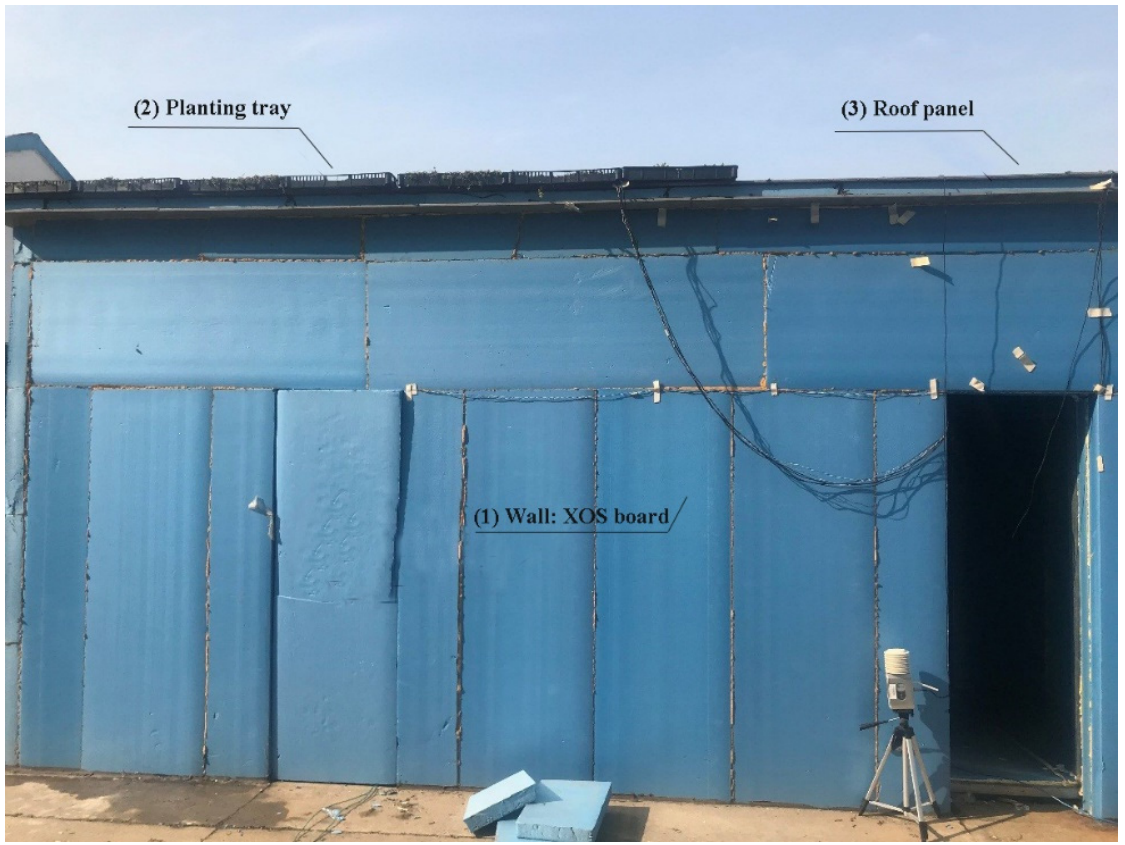

Fig. 4. Experimental room.

temperature was kept constant by adjusting the airconditioning. Two groups of measured data were compared and analyzed: sunny period in winter (2018.1.21-2018.1.24), and cooling and snowfall period in winter (2018.1.252018.1.28). The temperature was stable for four consecutive days during the two periods. Variations in the data curve for the sunny in winter period are shown in Figs. 5-7, and the curves for the period of cooling and snowfall in winter are shown in Figs. 8-10. Tables 2 and 3 provide the average values of the measured data. 


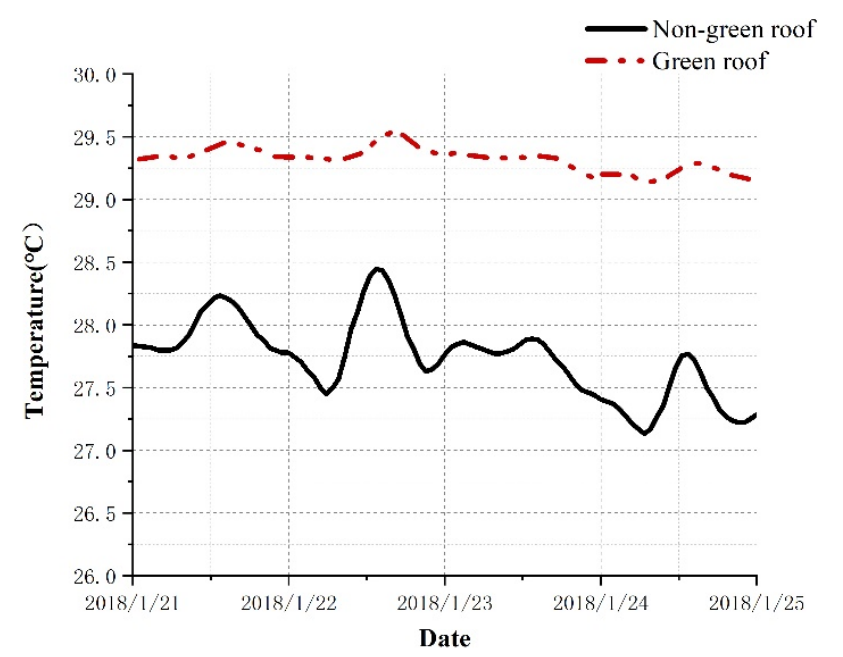

Fig. 5. Curve of internal surface temperature for the green and non-green roof plotted against time during the sunny period in winter.

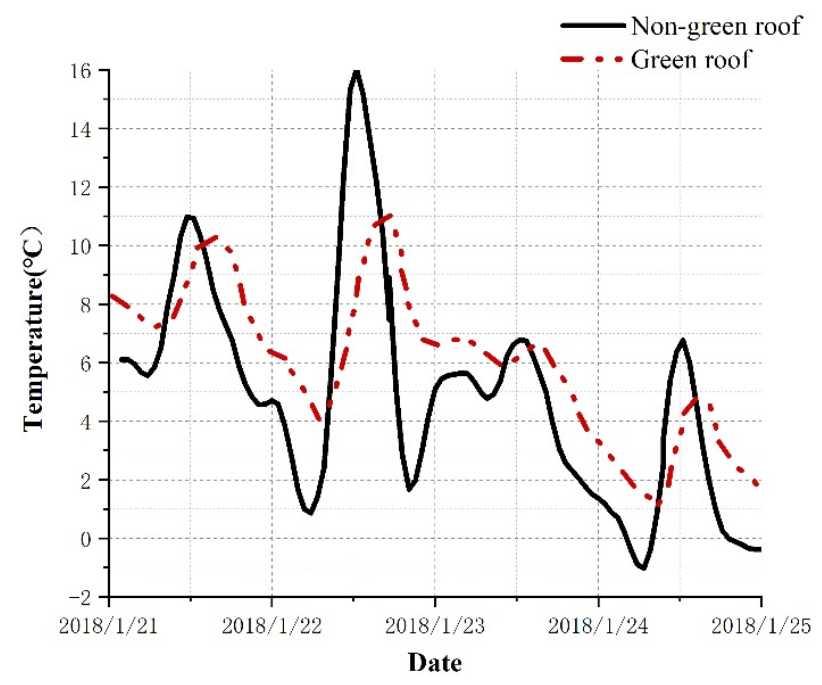

Fig. 6. Curve of outer surface temperature for the green and non-green roof plotted against time during the sunny period in winter.

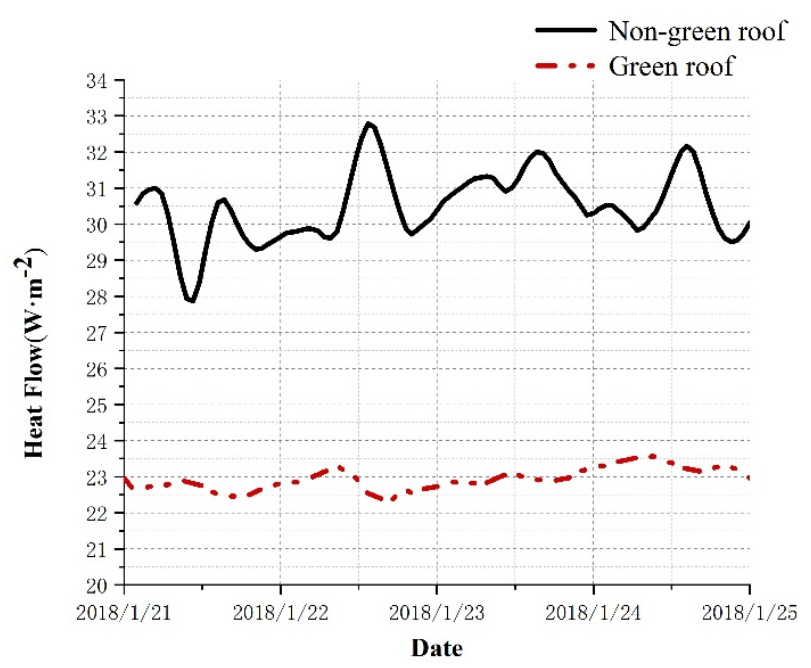

Fig. 7. Curve of the heat flow of the inner surface of the green and non-green roof plotted against time during the sunny period in winter. 


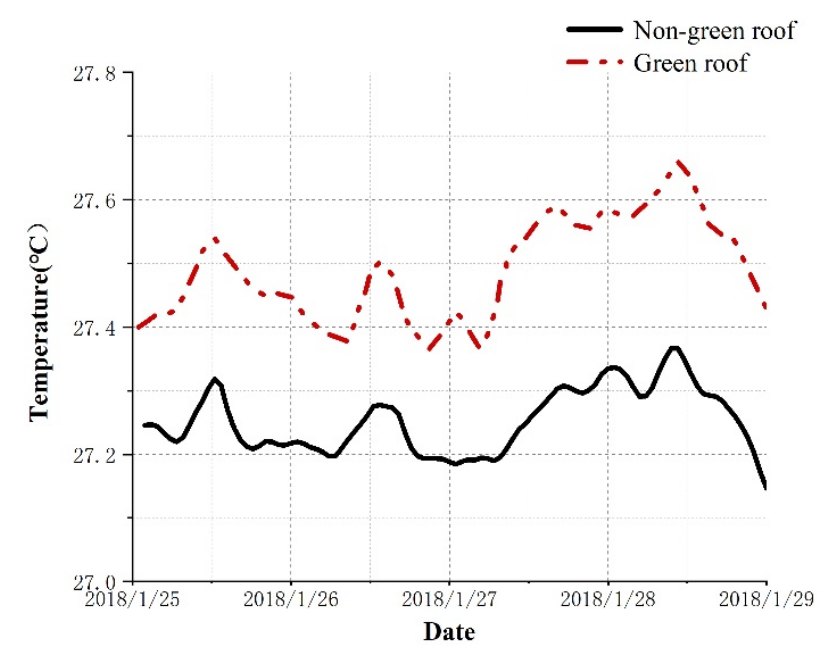

Fig. 8. Curve of internal surface temperature of the green and non-green roof plotted against time during the cooling and snowfall period in winter.

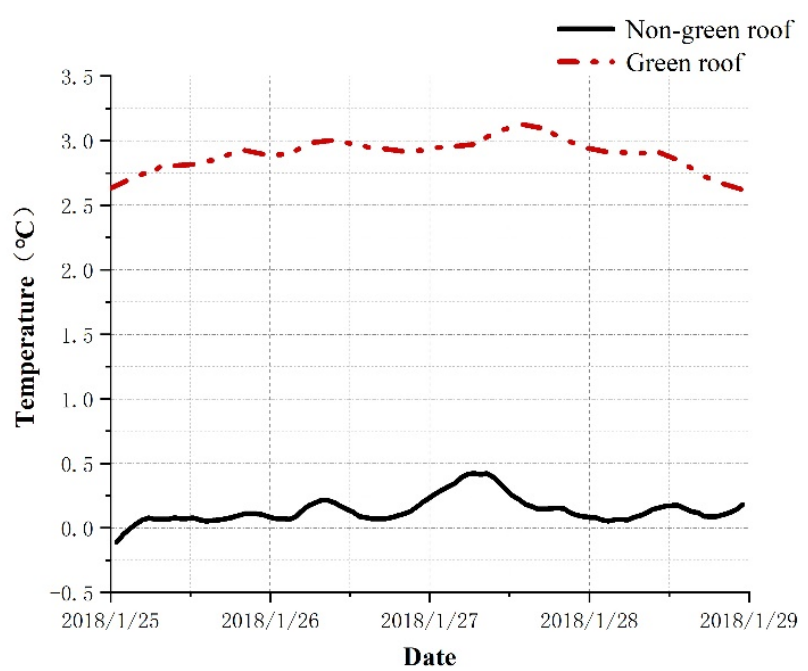

Fig. 9. Curve of outer surface temperature of the green and non-green roof plotted against time during the cooling and snowfall period in winter.

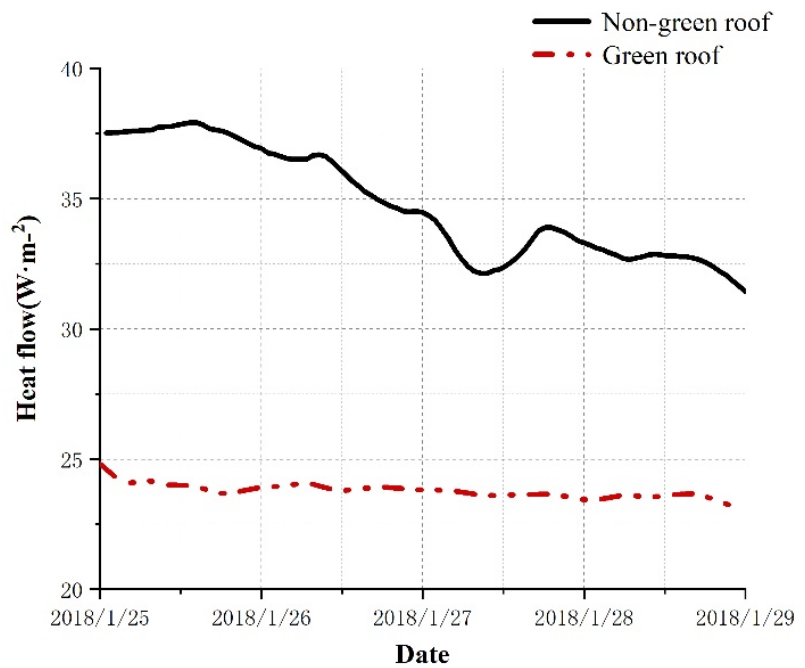

Fig. 10. Curve of the heat flow of the inner surface of the green and non-green roof plotted against time during the cooling and snowfall period in winter. 
Table 2. Average experimental data during the sunny weather period in winter.

\begin{tabular}{llllll}
\hline Parameter & $\begin{array}{l}\text { Outdoor } \\
\text { temperature } \\
\left({ }^{\circ} \mathrm{C}\right)\end{array}$ & $\begin{array}{l}\text { Room } \\
\text { temperature } \\
\left({ }^{\circ} \mathrm{C}\right)\end{array}$ & $\begin{array}{l}\text { Inner surface } \\
\text { temperature } \\
\left({ }^{\circ} \mathrm{C}\right)\end{array}$ & $\begin{array}{l}\text { External surface } \\
\text { temperature } \\
\left({ }^{\circ} \mathrm{C}\right)\end{array}$ & $\begin{array}{l}\text { Inner surface } \\
\text { heat flow } \\
\left.(\mathrm{W} \mathrm{m})^{-2}\right)\end{array}$ \\
\hline Green & 4.3 & 31.1 & 29.2 & 6.1 & 23.0 \\
Non-green & & 29.5 & 27.8 & 4.9 & 30.5 \\
Difference value & & +1.6 & +1.4 & +1.2 & -7.5 \\
Difference rate & & $5.4 \%$ & $5.0 \%$ & $24.5 \%$ & $-24.6 \%$ \\
\hline
\end{tabular}

Table 3. Average experimental data during the cooling and snowfall period in winter.

\begin{tabular}{llllll}
\hline Parameter & $\begin{array}{l}\text { Outdoor } \\
\text { temperature } \\
\left({ }^{\circ} \mathrm{C}\right)\end{array}$ & $\begin{array}{l}\text { Room } \\
\text { temperature } \\
\left({ }^{\circ} \mathrm{C}\right)\end{array}$ & $\begin{array}{l}\text { Inner surface } \\
\text { temperature } \\
\left({ }^{\circ} \mathrm{C}\right)\end{array}$ & $\begin{array}{l}\text { External surface } \\
\text { temperature } \\
\left({ }^{\circ} \mathrm{C}\right)\end{array}$ & $\begin{array}{l}\text { Inner surface } \\
\text { heat flow } \\
\left(\mathrm{W} \mathrm{m} \mathrm{m}^{-2}\right)\end{array}$ \\
\hline Green & 0.4 & 29.9 & 27.5 & 2.9 & 23.8 \\
Non-green & & 29.2 & 27.2 & 0.1 & 34.8 \\
Difference value & & +0.7 & +0.3 & +2.8 & -11.0 \\
Difference rate & & $2.4 \%$ & $1.1 \%$ & 28 & $-31.6 \%$ \\
\hline
\end{tabular}

According to the test data analysis, in the case where the indoor temperature of the air-conditioning control room of the green roof was the same as non-green roof, the inner surface temperature of the green roof was higher than that of the non-green roof in both periods, and the range of fluctuation of the green roof was more gentle, and the outer surface of the green roof was similar in terms of temperature. The range of fluctuation of heat flow and the heat flow on the inner surface of the green roof was much smaller than that of the non-green roof in both periods. The above experimental results show that the green roof has a good heat preservation effect, which will reduce the heat loss in a room and maintain the stability of the indoor thermal environment.

Equivalent thermal resistance is often used to evaluate the thermal insulation performance of building materials. The thermal resistance of the green roof layer cannot be directly measured by this instrument. Therefore, using the measured data obtained from this experiment, the difference in the values of the surface temperatures of the two sides of the structure was divided by the heat flow. The thermal resistance value was obtained using Eq. (1).

$\mathrm{R}=\left(\theta_{\mathrm{i}}-\theta_{\mathrm{e}}\right) / \mathrm{Q}$

where $\mathrm{R}$ is thermal resistance of enclosure structure $\left(\mathrm{m}^{2} \mathrm{~K} \mathrm{~W}^{-1}\right) ; \theta_{\mathrm{i}}, \theta_{\mathrm{e}}$ are the average temperature of the inner and outer surface of the enclosed structure $\left({ }^{\circ} \mathrm{C}\right)$, and $\mathrm{Q}$ is average heat flow on the inner surface of the enclosed structure $\left(\mathrm{W} \mathrm{m}^{-2}\right)$.

The thermal resistance $R_{1}$ and $R_{2}$ of the green and nongreen roof in the sunny period and cooling and snowfall in winter period during the constant temperature process were calculated, respectively, where the equivalent thermal resistance of the green layer was the difference between the thermal resistance of the green and non-green roof, $R_{1}-R_{2}$. The results are shown in Table 4. The experimental results show that the equivalent thermal resistance of the green roof in Wuxi could be taken as the average of the equivalent thermal resistance calculated from the two test data as $0.253 \mathrm{~m}^{2} \mathrm{~K} \mathrm{~W}^{-1}$.

\section{Heat Insulation Effect}

In order to obtain the heat insulation effect of the green roof, the experiment was carried out at high temperature in summer. Under constant room temperature control conditions, the measured data were compared and analyzed for the sunny in summer situation (2017.7.16-2017.7.19). The temperature was stable for four consecutive days during the sunny in summer period. Variations in the data curve for the sunny in summer period are shown in Figs. 11-13. Table 5 shows the average values of the measured data.

According to the test data analysis, in the case where the indoor temperature of the air-conditioning control room of the green roof was the same as non-green roof, the inner surface temperature of the green roof is lower than that of the non-green roof, and the range in fluctuation of the green roof is more gentle. The outer surface of the green roof is similar. The heat flow on the inner surface of the green roof is obviously lower than that of the non-green roof. The above experimental results show that the green roof has a good heat insulation effect, which can maintain a stable indoor thermal environment.

Table 4. Thermal resistance calculation results. $\left(\mathrm{m}^{2} \cdot \mathrm{K} \cdot(\mathrm{W})^{-1}\right)$

\begin{tabular}{llll}
\hline Date & $\begin{array}{l}\text { Thermal resistance of green } \\
\text { roof }: \mathrm{R}_{1}\end{array}$ & $\begin{array}{l}\text { Thermal resistance of non-green } \\
\text { roof: } \mathrm{R}_{2}\end{array}$ & $\begin{array}{l}\text { Equivalent thermal resistance } \\
\text { of the green layer: }\left(\mathrm{R}_{1}-\mathrm{R}_{2}\right)\end{array}$ \\
\hline $1 / 21-1 / 24$ & 1.007 & 0.760 & 0.247 \\
$1 / 25-1 / 28$ & 1.03 & 0.774 & 0.259 \\
Error $\Delta \mathrm{R}$ & 2.52 & $1.81 \%$ & $4.63 \%$ \\
\hline
\end{tabular}




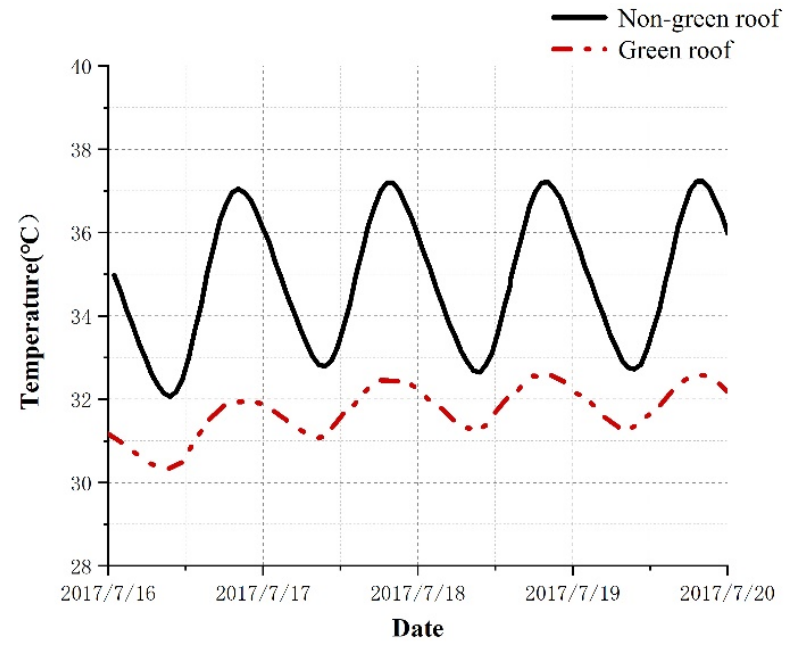

Fig. 11. Curve of internal surface temperature of the green and non-green roof plotted against time during the sunny period in summer.

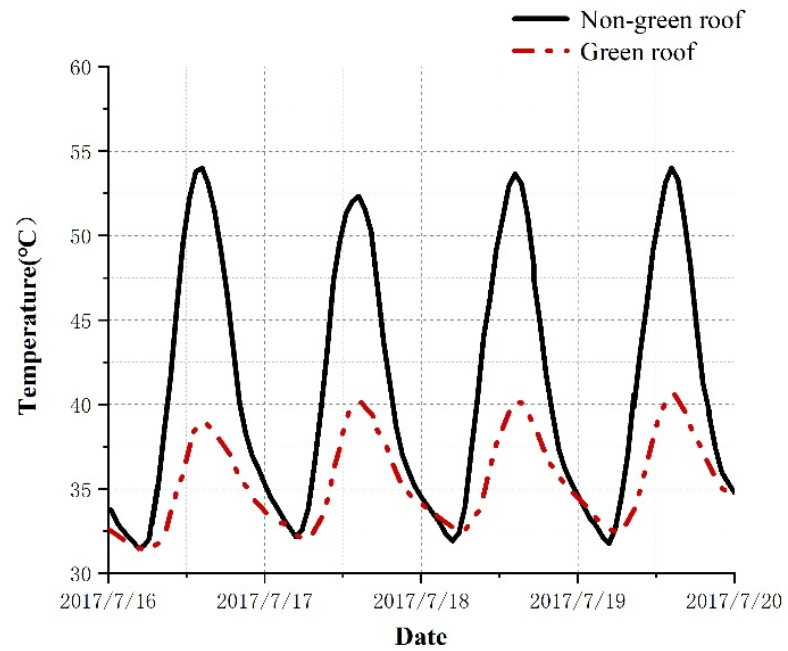

Fig. 12. Curve of outer surface temperature of the green and non-green roof plotted against time during the sunny period in summer.

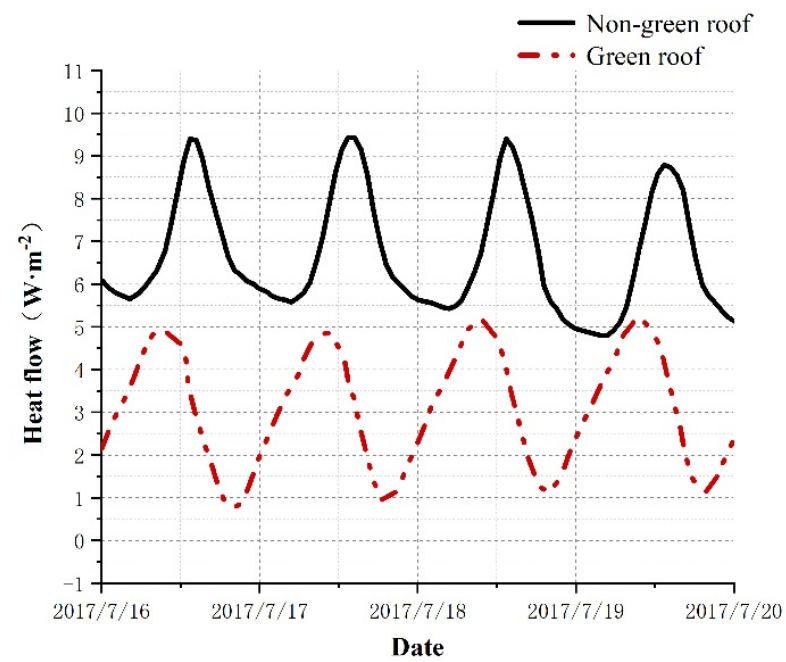

Fig. 13. Curve of the heat flow of the inner surface of the green and non-green roof plotted against time during the sunny period in summer. 
Table 5. Average experimental data during the sunny weather period in summer.

\begin{tabular}{llllll}
\hline Parameter & $\begin{array}{l}\text { Outdoor } \\
\text { temperature } \\
\left({ }^{\circ} \mathrm{C}\right)\end{array}$ & $\begin{array}{l}\text { Room } \\
\text { temperature } \\
\left({ }^{\circ} \mathrm{C}\right)\end{array}$ & $\begin{array}{l}\text { Inner surface } \\
\text { temperature } \\
\left({ }^{\circ} \mathrm{C}\right)\end{array}$ & $\begin{array}{l}\text { External surface } \\
\text { Temperature } \\
\left({ }^{\circ} \mathrm{C}\right)\end{array}$ & $\begin{array}{l}\text { Inner surface } \\
\text { heat flow } \\
\left.(\mathrm{W} \mathrm{m})^{-2}\right)\end{array}$ \\
\hline Green & 33.6 & 28.1 & 31.5 & 35.2 & 3.6 \\
Non-green & & 28.7 & 34.7 & 39.9 & 7.3 \\
Difference value & & -0.6 & -3.2 & -5.7 & -3.7 \\
\hline
\end{tabular}

\section{Energy-saving Effect}

During the experiment, an air-conditioning unit was used to control the two laboratory rooms to maintain a constant temperature, and the room temperature was the same. The energy-savings effect of the green roof was obtained by comparing and analyzing the air-conditioning electricity consumption of the green and non-green rooms, as shown in Table 6.

The data results show that under the same time period and temperature conditions, the air-conditioning power consumption for the experimental room with the green roof was less than that of the room with the non-green roof. In winter, the average daily energy-savings of air-conditioning in the green room was $0.37 \mathrm{kWh}$, and the average daily electricity savings rate for the air conditioners was $6.00 \%$. However in summer, the average daily energy-savings for the air-conditioning in the green room was $0.22 \mathrm{kWh}$, and the average daily electricity savings rate for air-conditioning was as high as $10.33 \%$. It can be seen that the green roof had a more significant energy-saving effect in summer than in winter.

Winter heating costs was calculated from November to February, and summer air conditioning costs was calculated from June to September, where it was found that the experimental room saved about $70.8 \mathrm{kWh}$ a year, and the green roof saved $11.8 \mathrm{kWh} \mathrm{m}^{-2} \mathrm{a}^{-1}$. The carbon emissions calculation formula generated by power plants is shown as Eq. (2).

$f_{1}=M_{1} \cdot K_{1}$

where $f_{1}$ is carbon emission reduction $(\mathrm{kg}) ; M_{1}$ is the amount of electricity savings $(\mathrm{kWh})$, and $K_{1}$ is electricity carbon emissions factor $\left(\mathrm{kg} \mathrm{CO}_{2}(\mathrm{kWh})^{-1}\right)$.
The National Development and Reform Commission determined that the baseline emission factor for the East China Regional Power Grid in 2015 was $0.811 \mathrm{~kg} \mathrm{CO}_{2} \cdot(\mathrm{kWh})^{-1}$. Therefore, based on the formula, a green roof can reduce carbon dioxide emissions by $11.8 \times 0.811=9.57 \mathrm{~kg} \mathrm{~m}^{-2} \mathrm{a}^{-1}$.

\section{Energy Consumption Simulation \\ Modeling and Calculation}

An office building located in the Binhu District of Wuxi was taken as an example to create a building model (see Fig. 14). The energy consumption of the building before and after the implementation of a green roof was simulated and analyzed using the Swell BESI2016 energy consumption analysis software based on BIM (Building Information Modeling). For the setting of the thermal performance of the roof, the thermal resistance of the green roof was based on the thermal resistance of the existing roof to which a green layer with equivalent thermal resistance was added. According to the actual measurement results in Wuxi, the equivalent thermal resistance of the green roof was $0.253 \mathrm{~m}^{2} \mathrm{~K} \mathrm{~W}^{-1}$ in winter and $1.465 \mathrm{~m}^{2} \cdot \mathrm{K} \mathrm{W}^{-1}$ in summer. The two values of the equivalent thermal resistance in winter and summer were substituted into the model for the energy consumption calculation.

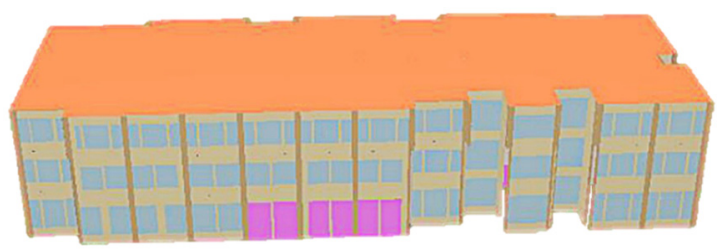

Fig. 14. Three-dimensional view of the office building model.

Table 6. Air-conditioning power consumption for the experimental rooms in winter and summer.

\begin{tabular}{llll}
\hline Date & Non-green room $/ \mathrm{kWh}$ & Green room $/ \mathrm{kWh}$ & Electricity saving rate \\
\hline Winter & & & \\
1.25 & 5.79 & 5.46 & $5.64 \%$ \\
1.26 & 5.97 & 5.68 & $4.81 \%$ \\
1.27 & 5.72 & 5.34 & $6.76 \%$ \\
1.28 & 5.59 & 5.11 & $8.45 \%$ \\
Average value & 5.76 & 5.39 & $6.00 \%$ \\
Summer & & & $7.76 \%$ \\
7.16 & 1.96 & 1.81 & $9.53 \%$ \\
7.17 & 2.17 & 1.96 & $11.74 \%$ \\
7.18 & 2.06 & 1.82 & $12.14 \%$ \\
7.19 & 2.15 & 1.89 & $10.33 \%$ \\
Average value & 2.09 & 1.87 & \\
\hline
\end{tabular}




\section{RESULTS AND DISCUSSION}

The results for the calculation of the annual energy consumption for the office building model are shown in Table 7 . The annual heat consumption of the building model after the use of a green roof in winter can be reduced by $7095 \mathrm{kWh}$ compared with that before greening, and the annual cooling consumption of building model after the use of a green roof in summer can be reduced by $6493 \mathrm{kWh}$ compared with that before greening. Generally speaking, after the implementation of the green roof, the total energy consumption for the whole year can be reduced by $13,588 \mathrm{kWh}$, and the green roof per unit area can save $11.53 \mathrm{kWh}$ per year. In the previous chapter, the experimental data showed that the green roof per square meter can save $11.8 \mathrm{kWh}$ per year. Compared with the experimental results, the error is only $2.3 \%$, and the data is thus deemed to be reliable. It can be seen that the energy consumption is greatly reduced, and the energy-saving effect is remarkable after the green roof reconstruction of the building.

\section{Analysis of Ecological Benefits \\ Quantitative Estimation of Ecological Benefits}

The ecological benefits of green roofs are much more than the direct economic benefits, so it is more meaningful to quantitatively calculate the ecological benefits of green roofs. Climate change is considered to be an unprecedented challenge in the world. Among these greenhouse gases, carbon dioxide emissions account for two-thirds of this concern. Therefore, reducing carbon dioxide emissions brings global challenges and opportunities for energy and environmental sustainability (Huang and Tan, 2014; Yu et al., 2016). Based on the benefits of carbon sequestration, oxygen release, air purification, rainwater management, energy-savings, and emissions reduction, combined with the price indexes such as hydropower in Wuxi City in 2018, this paper makes a quantitative analysis of green roof.

Plants can achieve the effect of fixing carbon dioxide through their own photosynthesis, which fixes carbon dioxide in the body and caused it to become dry matter. The chemical equation for plant photosynthesis is $\mathrm{CO}_{2}(264 \mathrm{~g})+\mathrm{H}_{2} \mathrm{O}(108 \mathrm{~g})$ $\rightarrow$ glucose $(180 \mathrm{~g})+\mathrm{O}_{2}(193 \mathrm{~g})$. It can be seen that plants can fix carbon dioxide and release oxygen through photosynthesis.

Beidari et al. (2017) believed that energy consumption is closely related to carbon dioxide. Plants on a green roof can absorb $\mathrm{CO}_{2}$ and release $\mathrm{O}_{2}$ at the same time through their own photosynthesis process. There is a certain significance to solving the problem of climate warming caused by greenhouse gas emissions. The vigorous summertime photosynthesis of vegetation results in lower $\mathrm{CO}_{2}$ concentrations during summer than during the other seasons (Cheng et al., 2019). In this experiment, photosynthetic and respiratory accumulations in the leaves of stonecrop were measured using a portable photosynthesis instrument (WALZ GFS3000, Germany). Photosynthetic carbon sequestration at a specific moment was obtained using instantaneous photosynthetic speed and respiratory rates. The experimental results showed that the green stonecrop roof can absorb $1.79 \mathrm{~kg}$ of $\mathrm{CO}_{2}$ and release $1.3 \mathrm{~kg}$ of $\mathrm{O}_{2}$ per square meter per year. The value of carbon sequestration is calculated according to the average value of the international carbon tax standard of USD $\$ 0.11 \mathrm{~kg}^{-1}$, and the value of releasing oxygen is calculated based on the price of industrial oxygen in China of USD $\$ 0.423 \mathrm{~kg}^{-1}$. Thus, the annual carbon sequestration and oxygen release benefit of the green roof of stonecrop per unit area is calculated to be USD $\$ 0.745$.

The existing roof area of Wuxi's main urban area is about 40 million $\mathrm{m}^{2}$. If one third of these roof were to be greened, the amount of carbon dioxide absorbed per year would be approximately $4000 \times 10^{4} \times 1 / 3 \times 1.79=23.867 \times 10^{6} \mathrm{~kg}$, which would absorb $23.867 \times 10^{6}$ tons of carbon dioxide every year.

A green roof can be used to purify the air through the planting layer and absorb harmful gases such as $\mathrm{SO}_{2}, \mathrm{NO}_{\mathrm{x}}$, dust, and respirable particulate matter in the air. According to research estimates, the annual uptake of harmful gases, mainly $\mathrm{SO}_{2}$, can reach 3.1 g per square meter on a green stonecrop roof in Wuxi, and the amount of adsorbed dust can reach $150 \mathrm{~g}$ per year, while absorbing about $270 \mathrm{~g}$ of $\mathrm{NO}_{\mathrm{x}}$ per year. According to the "Sewage Charge Collection Standards and Calculation Methods" promulgated by China, the sewage discharge fee for each discharge of $0.95 \mathrm{~kg} \mathrm{SO}_{2}$ and $\mathrm{NO}_{\mathrm{x}}$ is USD $\$ 0.085$ and USD \$0.339 respectively. Similarly, the fee for per $4 \mathrm{~kg}$ of general dust is USD $\$ 0.085$. From this, the annual benefit of purifying the air from the green roof can be calculated to be USD $\$ 0.1 \mathrm{~m}^{-2}$.

The soil and plants in a green roof layer have the ability to store water and can effectively retain roof rainwater when it rains. When the rainfall is significant, this can lighten the municipal administration drainage burden and alleviate the flood pressure on a city. The rainfall interception of the simple green roof in Wuxi was $21.5 \%$, and the annual rainfall in Wuxi in 2018 was $1322 \mathrm{~mm}$. Based on combined calculations, the annual rainwater interception flow per square meter of green roof would be $284.2 \mathrm{~kg}$, and based on the calculation of water price of USD $\$ 0.628 \mathrm{t}^{-1}$ in Wuxi, the annual benefit of rainwater management per unit area of green roof in Wuxi would be USD \$0.178.

Table 7. Annual energy consumption calculation results for the office buildings.

\begin{tabular}{lllll}
\hline & Season & $\begin{array}{l}\text { Annual cooling } \\
\text { Consumption } \\
(\mathrm{kWh})\end{array}$ & $\begin{array}{l}\text { Annual heat } \\
\text { Consumption } \\
(\mathrm{kWh})\end{array}$ & $\begin{array}{l}\text { Annual total } \\
\text { energy consumption } \\
(\mathrm{kWh})\end{array}$ \\
\hline Before greening & $\begin{array}{l}\text { Winter } \\
\text { Summer }\end{array}$ & 57986 & 76106 & 134092 \\
After greening & $\begin{array}{l}\text { Winter } \\
\text { Summer }\end{array}$ & 51493 & 69011 & 120504 \\
\hline
\end{tabular}


The energy-saving benefits of green roofs can be divided into two parts: One is the economic benefits brought about by the reduction in electricity consumption caused by the thermal insulation of the green roof, and the other is the indirect effect of the reduction in electricity consumption, which reduces the emission of air pollutants caused by power generation. The annual electricity consumption per square meter of the green stonecrop roof was $11.53 \mathrm{kWh}$, and the current electricity price of Wuxi is USD $\$ 0.0162(\mathrm{kWh})^{-1}$. Thus, the economic benefit was USD $\$ 0.188 \mathrm{~m}^{-2} \mathrm{a}^{-1}$. The emission of air pollutants in Wuxi is mainly $\mathrm{CO}_{2}$. Therefore, the reduction in $\mathrm{CO}_{2}$ emissions was used as an evaluation index by which to calculate the emission reduction benefits of the green roof and the corresponding energy-savings. The baseline emission factor was $0.811 \mathrm{~kg} \cdot \mathrm{CO}_{2} \cdot(\mathrm{kWh})^{-1}$, and the annual carbon emission reduction per unit area of the green roof in Wuxi was $9.35 \mathrm{~kg} \mathrm{~m}^{-2}$. The results show that the emission reduction benefit of the green roof was USD \$1.02 $\mathrm{m}^{-2} \cdot \mathrm{a}^{-1}$.

In summary, the quantitative results of the ecological benefits of the green roof per unit area are shown in Table 8 .

\section{Prediction of the Payback Time of the Investment of Green Roof}

The unit area cost of the simple green stonecrop roof used in the experiment was USD \$22.58, for which the annual maintenance cost is USD $\$ 0.706 \mathrm{~m}^{-2}$. The value of the benefits of the green roof was calculated as USD $\$ 3.37 \mathrm{~m}^{-2}$. The financial net present value of the green roof per unit area in the nth year is shown in Eq. (3). Taking 2018 as the first year, the financial net present value of the green roof per unit area is shown in Fig. 15.

$$
F N P V=\sum_{t=1}^{n}(3.37-0.7055) \times(1+i)^{-t}-22.58
$$

where $i$ is the financial benchmark rate of return for the construction industry, taking $3 \%$.

As can be seen from the Fig. 15, the financial net present value of the green roof exhibits a monotonous increasing trend, and the income increases with the increase in years. The net present value in the 10th year is positive, indicating that the payback time of the investment of the project is 10 years without government subsidies. In the fifteenth year, the net present value of the green roof would reach USD $\$ 8.95 \mathrm{~m}^{-2}$. So in the long run, the benefit is substantial.

\section{RESULTS AND DISCUSSION}

Through the study of a large number of measured data obtained from the experiments, it could be concluded that

Table 8. Value of ecological benefits for the green roof per unit area in Wuxi.

\begin{tabular}{llll}
\hline Evaluation index & & Quantity value & Benefit value (USD m \\
\hline Carbon sequestration and oxygen release & Absorb $\mathrm{CO}_{2}$ & $1.79 \mathrm{~kg}$ & 0.194 \\
& ${\text { Release } \mathrm{O}_{2}}^{*}$ & $1.30 \mathrm{~kg}$ & 0.550 \\
& ${\text { Absorb } \mathrm{SO}_{2}}^{\text {Air purification }}$ & $3.1 \mathrm{~g}$ & 0.00193 \\
& Absorb $\mathrm{NO}_{\mathrm{x}}$ & $270 \mathrm{~g}$ & 0.0962 \\
& Adsorptive dust & $150 \mathrm{~g}$ & 0.00317 \\
Rainwater management & Water conservation & $284.2 \mathrm{~kg}$ & 0.178 \\
Energy-saving and emission reduction & Electricity savings & $11.53 \mathrm{kWh}$ & 1.331 \\
& Reduced carbon emissions & $9.35 \mathrm{~kg}$ & 1.02 \\
Total value of benefits & & & 3.37 \\
\hline
\end{tabular}

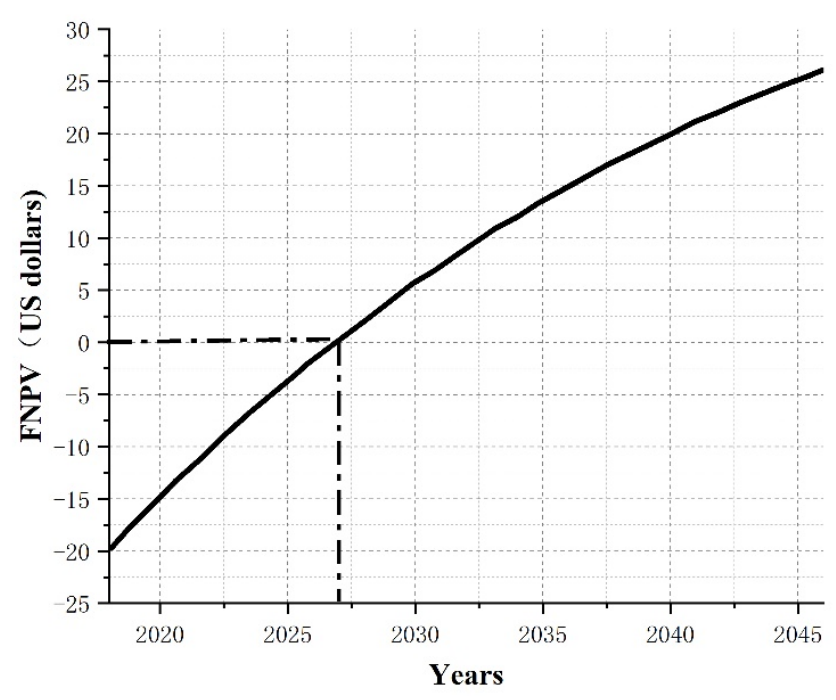

Fig. 15. Financial net present value of the green roof per unit area in Wuxi. 
the heat preservation, insulation performance, and energysaving benefits of green roofs are substantial. If the heating in winter is calculated from November to February and the air-conditioning in summer is calculated from June to September, the energy-savings for the experimental room was calculated to be approximately $70.8 \mathrm{kWh}$ per year. In terms of unit area, the green roof in the experimental room per square meter can save $11.8 \mathrm{kWh}$ per year. At the same time, through the simulation analysis of the energy consumption of a green roof in an office building, it has been concluded that the energy-saving per unit area would be $11.537 \mathrm{kWh}$ after the implementation of a green roof. Compared with the conclusions obtained from the simulation, the error is only $2.3 \%$, so the data is deemed reliable. The area of existing roofs in Wuxi is about $4000 \mathrm{hm}^{2}$. Using the results of the experiments, if one third of the roofs in Wuxi were to be transformed into green roofs for the purpose of saving energy, the annual energy savings could be as high as $1.57 \times 10^{8} \mathrm{kWh}$. According to the current electricity price standard in Wuxi, that would be USD $\$ 0.115(\mathrm{kWh})^{-1}$. Taking this measure would reduce electricity expenditures by nearly USD \$18 million. It can be seen that the green roof has great potential for saving energy and is worth promoting.

Li et al. (2016) suggested that with global warming and climate change, carbon dioxide accumulation in the air will cause some irreversible effects. Therefore, studying roof greening is important for reducing the impact of carbon dioxide. In the present study, the ecological benefits of green roofs were quantitatively analyzed by selecting indicators. According to the above assumptions, the quantitative effects of the green roof project in Wuxi on improving the urban ecological environment are as follows: release $1.73 \times 10^{4} \mathrm{t}$ of $\mathrm{O}_{2}$, reduce $1.49 \times 10^{5}$ t of $\mathrm{CO}_{2}$ emissions (including $\mathrm{CO}_{2}$ absorbed by green plants and energy-saving and emission reduction), absorb $2.0 \times 10^{3} \mathrm{t}$ of dust, $41.3 \mathrm{t}$ of $\mathrm{SO}_{2}$ and 3.6 $\times 10^{3} \mathrm{t}$ of $\mathrm{NO}_{\mathrm{x}}$, intercept rainwater in the amount of $3.79 \times$ $10^{6} \mathrm{t}$, and save electricity by $1.54 \times 10^{8} \mathrm{kWh}$. The total ecological benefit is USD $\$ 3.37 \mathrm{~m}^{-2}$. Then, the annual ecological benefit of green roof renovation for one third of the roofs in Wuxi would be approximately USD \$42 million. In terms of the financial net present value, the green roof project in Wuxi in the $15^{\text {th }}$ year would generate USD $\$ 122$ million. It can be seen that large-scale application of green roofs would have remarkable ecological benefits, play a role in protecting the environment and saving resources, and would promote rapid economic development in cities and countries.

Since the benefits generated by green roofs may have less impact on developers themselves, they are more likely to be shared by the entire society and a wider audience. Therefore, the government should formulate a corresponding ecological compensation system. Financial incentives could be introduced, such as subsidies and tax reductions (Ulubeyli and Arslan, 2017; Berto et al., 2018). There are also other incentives, such as increasing the land plot ratio, among other ways to compensate investors. Industry organizations need to organize better and develop more targeted education programs to promote the development of green roofs (Tassicker et al., 2016). In this way, both private and social benefits can be achieved to better promote the construction of green roof projects as an essential component of urban development planning.

\section{CONCLUSIONS}

Green roofs can effectively block outdoor heat when the outdoor temperature is low in winter, and they can prevent outdoor heat from entering indoor environments when the outdoor temperature is high in summer, which has beneficial effects, including heat preservation and insulation. According to the actual measurement and analysis, it was found that in the hot summer and cold winter areas represented by Wuxi, the green roof per square meter can save $11.53 \mathrm{kWh}$ of electricity per year. Therefore, green roofs play an important role in energy-savings and consumption reduction.

Green roofs not only absorb $\mathrm{CO}_{2}$, dust, $\mathrm{SO}_{2}$, and other atmospheric pollutants and thus purify the air, but they also release $\mathrm{O}_{2}$, store rainwater, alleviate urban waterlogging and the heat island effect, with remarkable ecological benefits. The plants on the roof absorb gaseous pollutants through their pores, absorb granular pollutants through the fluff grown on the surface of the leaves, and decompose organic pollutants in the tissues and soil, thus absorbing harmful gases such as $\mathrm{SO}_{2}$ and $\mathrm{NO}_{\mathrm{x}}$ in the atmosphere, as well as suspended particles The experimental results show that a green stonecrop roof can absorb $1.79 \mathrm{~kg}$ of $\mathrm{CO}_{2}$ and release $1.3 \mathrm{~kg}$ of $\mathrm{O}_{2}$ per square meter per year. In addition, the annual carbon emission reduction per unit area of the green roof in Wuxi was $9.35 \mathrm{~kg} \mathrm{~m}^{-2}$, and the emission reduction benefit of the green roof was calculated to be USD $\$ 1.02 \mathrm{~m}^{-2} \mathrm{a}^{-1}$. According to the analysis, in the hot summer and cold winter areas represented by Wuxi, the quantitative ecological benefit of green roof would be USD $\$ 3.37 \mathrm{~m}^{-2} \mathrm{a}^{-1}$, for which the payback time for the investment would be 10 years. The economic benefits of the green roof are huge, and thus they should be vigorously promoted.

Green roofs have benefits including promoting building energy conservation and emission reduction and improving the ecological environment. However, due to the various forms of green roofs and the different climatic characteristics of different areas, the construction methods for building roofs are also different. Also, the benefits of green roof vary. Therefore, in order to achieve more effective implementation and application of green roofs, there are more aspects worthy of further study.

\section{ACKNOWLEDGMENTS}

This work was supported by the National Nature Science Foundation of China [grant numbers 51378240], the 2018 Science and Technology Department's Social Development Project [grant numbers BE2018625], the 2016 Jiangsu Province Building Energy Efficiency Technology Support Project, the Jiangsu provincial construction industry modern demonstration project, and the 2015 Jiangsu provincial building energy saving and construction industry science and technology project. 


\section{REFERENCES}

Agra, H., Klein, T. Vasl, A., Shalom, H., Kadas, G. and Blaustein, L. (2017). Sedum-dominated green-roofs in a semi-arid region increase $\mathrm{CO}_{2}$ concentrations during the dry season. Sci. Total Environ. 584: 1147-1151.

Akbari, H. (2003). Measured energy savings from the application of reflective roofs in two small non-residential buildings. Energy 28: 953-967.

Beidari, M., Lin, S. and Lewis, C. (2017). Multiplier effects of energy consumption and $\mathrm{CO}_{2}$ emissions by inputoutput analysis in south Africa. Aerosol Air Qual. Res. 17: 1666-1678.

Berardi, U., GhaffarianHosein, A. and GhaffarianHosein, A. (2014). State-of-the-art analysis of the environmental benefits of green roofs. Appl. Energy 115: 411-428.

Berardi, U. (2016). The outdoor microclimate benefits and energy saving resulting from green roofs retrofits. Energy Build. 121: 217-229.

Berto, R., Stival, C. and Rosato, P. (2018). Enhancing the environmental performance of industrial settlements: An economic evaluation of extensive green roof competitiveness. Build. Environ. 127: 58-68.

Bevilacqua, P., Mazzeo, D. and Arcuri, N. (2018). Thermal inertia assessment of an experimental extensive green roof in summer conditions. Build. Environ. 131: 264-276.

Brudermann, T. and Sangkakool, T. (2017). Green roofs in temperate climate cities in Europe - An analysis of key decision factors. Urban For Urban Gree. 21: 224-234.

Chen, P., Li, Y., Lo, W. and Tung, C. (2015). Toward the practicability of a heat transfer model for green roofs. Ecol. Eng. 74: 266-273.

Cheng, L., Ji, D., He, J., Li, L., Du, L., Cui, Y., Zhang, H., Zhou, L., Li, Z., Zhou, Y., Miao, S., Gong, Z. and Wang, Y. (2019). Characteri-stics of air pollutants and greenhouse gases at a regional background station in southwestern China. Aerosol Air Qual. Res. 19: 1007-1023.

Collins, S., Kuoppamäki, K., Kotze, D. and Lü, X. (2017). Thermal behavior of green roofs under Nordic winter conditions. Build. Environ. 122: 206-214.

Coma, J., Perez, G., Sole, C., Castell, A. and Cabeza, L. (2016). Thermal assessment of extensive green roofs as passive tool for energy savings in buildings. Renewable Energy 85: 1106-1115.

Francis, L. and, Jensen, M. (2017). Benefits of green roofs: A systematic review of the evidence for three ecosystem services. Urban For. Urban Greening 28: 167-176.

He, Y., Yu, H., Dong, N. and Ye, H. (2016). Thermal and energy performance assessment of extensive green roof in summer: A case study of a lightweight building in Shanghai. Energy Build. 127: 762-773.

Herrera-Gomez, S., Quevedo-Nolasco, A. and PérezUrrestarazu, L. (2017). The role of green roofs in climate change mitigation. A case study in Seville (Spain). Build. Environ. 123: 575-584.

Huang, C. and Tan, C. (2014). A review: $\mathrm{CO}_{2}$ utilization. Aerosol Air Qual. Res. 14: 480-499.

Jim, C. (2014). Passive warming of indoor space induced by tropical green roof in winter. Energy 68: 272-282.
Jim, C. (2015). Assessing climate-adaptation effect of extensive tropical green roofs in cities. Landscape Urban Plann. 138: 54-70.

Kuronuma, T., Ishihara, T., Kou, D., Toushima, K., Ando, M. and Shindo, S. (2018). $\mathrm{CO}_{2}$ payoff of extensive green roofs with different vegetation species. Sustainability 10 : 2256.

La Roche, P. and Berardi, U. (2014). Comfort and energy savings with active green roofs. Energy Build. 82: 492504.

Li, H. (2011). Study on selection and ecological benefits of roof greening plants in Guangzhou city. Ph.D. Thesis, South China University of Technology, China.

Liu, Y., Yang, Z., Zhu, M. and Yin, J. (2017). Role of plant leaves in removing airborne dust and associated metals on Beijing roadsides. Aerosol Air Qual. Res. 17: 2566-2584.

Meng, Z., Zhang, R., Lin, W., Jia, X., Yu, X., Yu, X. and Wang, G. (2014). Seasonal variation of ammonia and ammonium aerosol at a background station in the Yangtze River Delta region, China. Aerosol Air Qual. Res. 14: 756-766.

Mohamed, B., Lin, S. and Lewis, C. (2017). Multiplier effects of energy consumption and $\mathrm{CO}_{2}$ emissions by input-output analysis in south Africa. Aerosol Air Qual. Res. 17: 1666-1678.

Peng, L. and Jim, C. (2015). Economic evaluation of greenroof environmental benefits in the context of climate change: The case of Hong Kong. Urban For. Urban Greening 14: 554-561.

Ping, L., Pan, S., Pei, S., Lin, Y. and Chiang, P. (2016). Challenges and perspectives on carbon fixation and utilization techn-ologies: An overview. Aerosol Air Qual. Res. 16: 1327-1344.

Refahi, A. and Talkhabi, H. (2015). Investigating the effective factors on the reduction of energy consumption in residential buildings with green roofs. Renewable Energy 80: 595-603.

Shafique, M., Kim, R. and Rafiq, M. (2018). Green roof benefits, opportunities and challenges - A review. Renewable Sustainable Energy Rev. 90: 757-773.

Silva, C., Gomes, M., Silva and M. (2016). Green roofs energy performance in Mediterranean climate. Energy Build. 116: 318-325.

Squier, M. and Davidson, C. (2016). Heat flux and seasonal thermal performance of an extensive green roof. Build. Environ. 107: 235-244.

Tang, X. and Qu, M. (2016). Phase change and thermal performance analysis for green roofs in cold climates. Energy Build. 121: 165-175.

Tassicker, N., Rahnamayiezekavat, P. and Sutrisn, M. (2016). An insight into the commercial viability of green roofs in Australia. Sustainability 8: 603.

Teotonio, I., Silva, C. and Cruz, C. (2018). Eco-solutions for urban environments regeneration: The economic value of green roofs. J. Cleaner Prod. 199: 121-135.

Ulubeyli, S. and Arslan, V. (2017). Economic viability of extensive green roofs through scenario and sensitivity analyses: Clients' perspective. Energy Build. 139: 314325. 
Vasl, A., Shalom, H., Kadas, G. and Blaustein, L. (2017). Sedum-Annual plant interactions on green roofs: Facilitation, competition and exclusion. Ecol. Eng. 108: 318-329.

Virk, G., Jansz, A., Mavrogianni, A., Mylona, A., Stocker, J. and Davies, M. (2015). Microclimatic effects of green and cool roofs in London and their impacts on energy use for a typical office building. Energy Build. 88: 214-228.

Wang, X., Li, Z., Cai, C., Zhihua, S., Xu, Q., Fu, Z. and Guo, Z. (2013). Hydrological response of sloping farmlands with different rock fragment covers in the purple soil area of China. J. Hydrol. Eng. 18: 446-456.

William, R., Goodwell, A., Richardson, M., Le, PV., Kumar, P. and Stillwell, A. (2016). An environmental cost-benefit analysis of alternative green roofing strategies. Ecol. Eng. 95: 1-9.

Yang, D., Li, Q. and Zhang, L. (2019). Characteristics of carbon dioxide emissions from a seismically active fault. Aerosol Air Qual. Res. 19: 1911-1919.

Yang, J., Liu, H. and Sun, J. (2018). Evaluation and application of an online coupled modeling system to assess the interaction between urban vegetation and air quality. Aerosol Air Qual. Res. 18: 693-710.

Yu, J.Y., Chang, K.H. and Chen, T.F. (2016). Estimation of $\mathrm{CO}_{2}$ assimilation and emission flux of vegetation in subtropical island - Taiwan. Aerosol Air Qual. Res. 16: 3302-3311.

Zeng, C., Bai, X., Sun, L., Zhang, Y. and Yuan, Y. (2017). Optimal parameters of green roofs in representative cities of four climate zones in China: A simulation study. Energy Build. 150: 118-131.

Zhang, S., Tian, M. and Zhao, M. (2009). Cost-benefit analysis of roof greening construction project in Beijing. Urban forestry in China. 4: 61-63.

Zhao, M., Srebric, J., Berghage, R. and Dressler, K. (2015). Accumulated snow layer influence on the heat transfer process through green roof assemblies. Build. Environ. 87: 82-91.

Received for review, September 13, 2019

Revised, September 24, 2019 Accepted, October 5, 2019 